\title{
The Effect of Heat Exchanger Design on Heat Transfer Rate and Temperature Distribution
}

\author{
Saad S. Alrwashdeh ${ }^{1,2 *}$, Handri Ammari ${ }^{1}$, Mazen A. Madanat ${ }^{3}$, Ala'a M. Al-Falahat ${ }^{1,2}$ \\ ${ }^{1}$ Mechanical Engineering Department, Faculty of Engineering, Mutah University, P.O Box 7, Al-Karak 61710 Jordan \\ ${ }^{2}$ Materials Science and Energy Lab, MSEL. Mutah University, P.O Box 7, Al-Karak 61710 Jordan. \\ ${ }^{3}$ Light Metal Alloys Research Unit, Advanced Research Centre, Royal Scientific Society, Amman, 11941, Jordan.
}

\begin{abstract}
The heat exchanger (HE) is a device that is used to complete the process of heat transfer between different matters without direct mixing. Therefore, it is of great importance in the transfer of energy and the completion of various energy transition processes. In the processes of HE between different energy systems, many factors influence and play a major and important role in the efficiency of transformation and exchange in forms of energy, such as the length, the material type, the exchange fluid, the surrounding environment, and many other factors. In this work, the effect of the HE length of the parallel and counter flow HEs was investigated based on the use of computer simulation programs. There was a significant impact of the exchange factors, especially the length of the HEs in both the parallel and counter-flow HEs, on the quality and efficiency of the $\mathrm{HE}$ and the temperature distribution. The overall evaluation shows that by increasing the length of the HE for both parallel and counter-flow HEs, the heat transfer is increased and the heat distribution becomes more homogeneous, which aids in enhancing the transfer of energy efficiency inside the HEs.
\end{abstract}

Keywords:

Heat Exchanger;

Heat Transfer;

Energy;

Parallel and Counter Heat Exchanger.

\section{Article History:}

$\begin{array}{llll}\text { Received: } & 05 & \text { October } & 2021 \\ \text { Revised: } & 26 & \text { November } & 2021 \\ \text { Accepted: } & 04 & \text { January } & 2022 \\ \text { Published: } & 01 & \text { February } & 2022\end{array}$

\section{1- Introduction}

Energy is one of the most important factors that affect the stability of any system, and thus, dealing with different energy systems is very important to achieve the greatest possible benefit from energy sources [1-3]. Energy sources are divided into conventional and renewable sources, and both types participate in securing the necessary energy to complete the requirements of the various engineering systems, and they also participate to a large extent in some support systems to complete the utilization of the energy of various kinds [4-6]. We found many studies around the world concerned with traditional energy sources, determining their whereabouts and the best ways to benefit from them, as well as the matter of renewable energy sources, as many studies and evaluations of renewable energy sources have emerged as a solution and a basic alternative to traditional energy sources [7-9]. Studying energy sources alone is considered insufficient to determine the greatest benefit from them [10-12]. Here, work is highlighted in the aid of systems that are concerned with utilizing energy, such as turbines of all kinds, boilers of all kinds, coolers, pumps, and other support systems [13-15]. The HE is considered one of the most important systems that help in the process of completing the various energy cycles, as it is based on completing the transfer of heat from the different parts of the systems without the need for physical mixing [16-18].

* CONTACT: saad.alrwashdeh@mutah.edu.jo

DOI: http://dx.doi.org/10.28991/ESJ-2022-06-01-010

(C) 2022 by the authors. Licensee ESJ, Italy. This is an open access article under the terms and conditions of the Creative Commons Attribution (CC-BY) license (https://creativecommons.org/licenses/by/4.0/). 
Energy recovery in industrial and engineering facilities is one of the most important issues that greatly impacts on saving and sustaining work, as the energy losses in such facilities are very large and costly [19-21]. Here, work is highlighted in the use and development of various HEs to maximize energy utilization and recycle the possibilities of them [22-24]. The HE is used with various conventional or renewable energy systems as this device is used to complete engineering cycles, and in the absence of this device, some systems are unable to complete their work and achieve benefit from them [25-27]. Also, the system may be completely disabled due to the absence or failure of the HE [2830]. Here is the importance of defining the HE, and it is defined as a device used to transfer heat between different materials without direct mixing. This is done through tubes that transport different materials, and these tubes are exposed directly to each other, leading to heat transfer [2, 23, 31]. Heat transfer operations using HEs depend on many important factors, and among those factors is the shape of the $\mathrm{HE}[22,32,33]$.

Here, the most important forms of HEs stand out, which are the parallel HEs, which work so that the flow of materials is completely in the same direction, and the counter HEs, in which the flow of materials is in the opposite direction, that is, the hot material is in one direction and the cold material is in the opposite direction [34-36]. Other conditions that influence the HE processes stand out, such as the type, which has an effect on the quality of the HE, but a number of other factors are no less important, including the flow rate inside the HE, the length of the HE, the nature of the materials used in the manufacture of the HE, and the lifecycle of the HE [37-39]. Many researchers around the world have studied ways to develop HE in order to maximize its benefits. There are several techniques for shell and tube HE enhancement: shell enhancement and tube enhancement. Shell enhancement works on the flow shape with different styles, such as the flower barriers [40] and the helical barriers [26]. There are different barrier styles, such as flow with diverse patterns in the shell, which have an impact on the efficiency. Kozeki et al. [41] studied the helically-coiled HE with stainless steel tubes. The results illustrated that the exchange quality affects the local heat transfer coefficient.

As noted before, the heat transfer improvement in shell and tube HE is considered part of the improvement of the shell or tube side. The tube enhancement is not only for tubers that belong to shell-tube HE but also for the other HE. Relying on the design conditions for HE, a large transfer area means enhancing the heat transfer. The fins are one of the ideas to maximize the area of the transfer. Desai et al. [42] investigated the fluid vibrations inside the HE provided by fins. He found that the fine arrays are stable, which aids in the stability of the HE body. Deng et al. [43] presented a study about the thermal storage with the HE provided by fins, and he found that the fins play a major role in storing the thermal energy. Different HEs are used according to the requirements [44]. Guo et al. [45] provided a design module for the HEs aimed at reducing the volume of the exchanger, with the aim of reducing the cost of the fabrication. Wang et al. [46] present work regarding the pattern and optimization of the multi-layer exchangers. The exchanger provided with the fin is widely used with low-pressure exchangers [47].

The new circuit HE is made from several plates and connected by diffusion bonding. The operating conditions deal with the channel system of the plates. The new conditions lead to a complex design. An example of the diffusion-bonded process is copper-nickel, nickel alloys, and titanium [25]. Figley et al. [48] studied the structure of the HE using numerical simulation and found a major effect of the structure on the HE work. Zheng et al. [49] developed a new channel with a new shape of the HE to investigate the efficiency. A transient flow is detected by the new design. Ma et al. [50] study the inclination of a new design numerically of the HE and the drop in the pressure.

Simulation software is one of the most important engineering tools in investigating information about the work of engineering devices, as this software is based on simulating the virtual reality of working conditions and calculating expectations and the effects resulting from operating these various systems [49, 51, 52]. As a result of what simulation programs are doing, many industrial and engineering systems have been developed recently, as these programs reflect a clear picture of the work of the different systems and indicate potential faults and ways to address them during engineering design, even in some cases after implementing the design in reality [45, 48]. The simulation programs give hope of modifying the realistic designs with the lowest effort, cost, and best possible performance [32, 53, 54]. In this study, the operational and design conditions of the HE are highlighted, such as the flow rate of the matter inside the HEs, the length of the HE, and the effect of these conditions on the efficiency of the HEs.

\section{2- Heat Exchange Theory}

Typically, HEs are classified according to the internal arrangement, flow profile, and internal structure. One of the most widespread HEs depends on the flow of fluids inside it, so hot and cold fluids flow in the same direction or in the opposite direction in what is known as the parallel-flow or counter-flow HE, respectively. Figure. 1 shows the types of HEs used in this study, where the Figure 1A refers to the parallel flow HE, while the Figure 1B refers to the counter flow HE. 


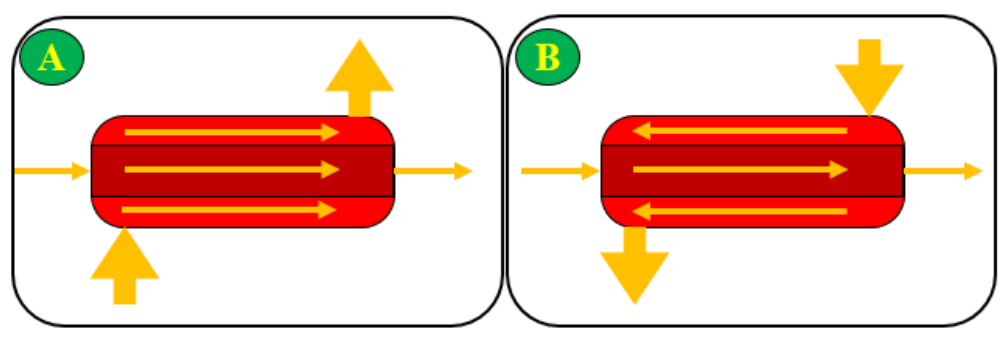

Figure 1. Parallel flow HE (A), Counter flow HE (B)

The heat exchange calculations inside the HEs start by calculating the value of the overall heat exchange coefficient as shown in the equations below. This is followed by the calculation of the heat transfer rates, taking into account the different temperatures of the hot inlet and the cold inlet and their exits as well, so that the effect of heat exchange can be properly studied along the length of the HE and then shows the effect of HE conditions on the heat exchange value.

$\frac{1}{U . A}=\frac{1}{(h \cdot A) c}+R_{w}+\frac{1}{(h \cdot A) h}$

Taking into the consideration the effects of the fouling factors " $R_{f}$ " where it can be extracted as a fixed value based on the system used such as steam, refrigeration liquid, and others as well as the temperature effectiveness of all surfaces. Then the above equation will be:

$$
\frac{1}{U \cdot A}=\frac{1}{\left(\eta_{o} \cdot h \cdot A\right) c}+\frac{R_{f . c}^{\prime \prime}}{\left(\eta_{o} \cdot A\right) c}+R_{w}+\frac{R_{f \cdot h}^{\prime \prime}}{\left(\eta_{o} \cdot A\right) h}+\frac{1}{\left(\eta_{o} \cdot h \cdot A\right) h}
$$

Where; $\eta_{o}=1-\frac{A_{f}}{A}\left(1-\eta_{f}\right)$

Table 1 shows the values of the overall heat transfer coefficients as well as the values of the fouling factors for the selected systems.

Table 1. Overall heat transfer coefficient and fouling factors for selected systems

\begin{tabular}{cccc}
\hline Fluid & $\mathbf{R}_{\mathbf{f}}\left(\mathbf{m}^{2} \cdot \mathbf{K} / \mathbf{w}\right)$ & Fluid combination & $\mathbf{U}\left(\mathbf{W} / \mathbf{m}^{2} \cdot \mathbf{K}\right)$ \\
\hline Seawater and treated boiler feed water below $50{ }^{\circ} \mathrm{C}$ & 0.0001 & Water to water & $850-1700$ \\
Seawater and treated boiler feed water above $50{ }^{\circ} \mathrm{C}$ & 0.0002 & Water to oil & $110-350$ \\
River water & $0.0002-0.001$ & Steam condenser & $1000-6000$ \\
Fuel oil & 0.0009 & Ammonia condenser & $800-1400$ \\
Refrigeration liquid & 0.0002 & Alcohol condenser & $250-700$ \\
Steam & 0.0001 & Finned-tube & $25-50$ \\
\hline
\end{tabular}

To design the HE several factor taken into the consideration based on the temperature distribution. The log mean temperature difference approach is considered for the design as the following:

$q=\dot{m}_{h}\left(i_{h, i}-i_{h, o}\right)$

and,

$q=\dot{m}_{c}\left(i_{c, o}-i_{c, i}\right)$

The above equations can be rewritten in term of using the temperate difference as:

$q=\dot{m}_{h} \cdot C_{p . h}\left(T_{h, i}-T_{h, o}\right)$

and,

$q=\dot{m}_{c} \cdot C_{p . c}\left(T_{c, o}-T_{c, i}\right)$

Finally, the overall heat transfer expressed as the Equation 3;

$q=U \cdot A \cdot \Delta T_{m}$

For the parallel and counter HE, the total heat exchange is based on the temperature difference as log mean difference which is deeply depend on the structure of the HE as it is clear from the Figure 2. The heat transfer is depending on the structure of the $\mathrm{HE}$ as the amount of the heat at each stage effected by the direction of the flow. As a part of the structure effect the length of the exchanger effect the amount of the heat transfer as well as it can reduce or increase the time of the heat exchange. 


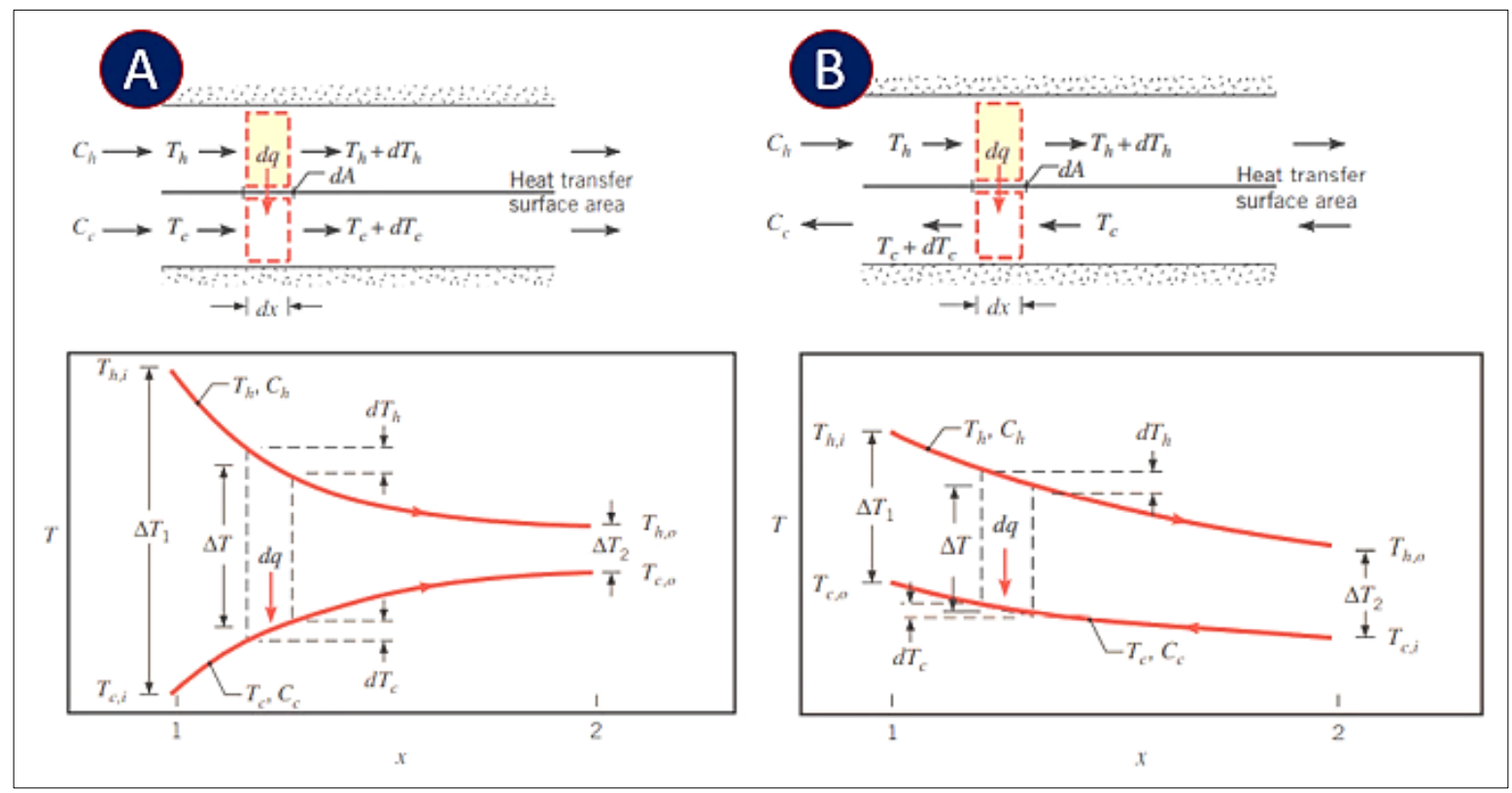

Figure 2. The temperature distribution in the (A) Parallel HE, (b) Counter HE

The log mean temperature is calculated based on the structure of the HE with an assumption of insulated HE from its surrounding, negligible axial conduction along the tube, constant fluid specific heat, and constant overall heat transfer coefficient. So the log mean temperature can be given as:

$\Delta T_{l m}=\frac{\Delta T_{2}-\Delta T_{1}}{\ln \left(\Delta T_{2} / \Delta T_{1}\right)}=\frac{\Delta T_{1}-\Delta T_{2}}{\ln \left(\Delta T_{1} / \Delta T_{2}\right)}$

Where, the parallel-flow exchanger temperature condition is:

$\Delta T_{1}=T_{h, 1}-T_{c, 1}=T_{h, i}-T_{c, i}$

$\Delta T_{2}=T_{h, 2}-T_{c, 2}=T_{h, o}-T_{c, o}$

and, the counter-flow exchanger temperature condition is:

$\Delta T_{1}=T_{h, 1}-T_{c, 1}=T_{h, i}-T_{c, o}$

$\Delta T_{2}=T_{h, 2}-T_{c, 2}=T_{h, o}-T_{c, i}$

Figure 3 shows the flowchart of the work which is started from the HE selection to be parallel or counter flow the simulation code is run with different input of the HE length to the final step which is the result extraction which reflect the best length as well as the highest efficiency of the investigated HEs.

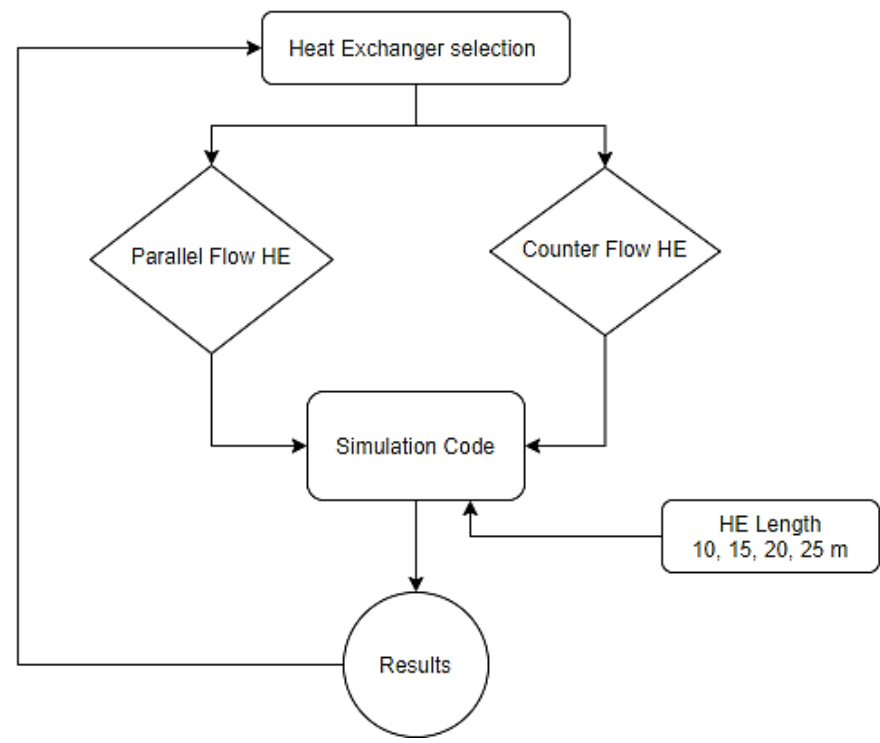

Figure 3. Research Methodology flowchart 
The research methodology depends on testing the effect of the HEs lengths that start 10, 15, 20, and $25 \mathrm{~m}$ by using the simulation program code to re-work each time with a different length and comparing the effect of that length on the heat exchange and the temperature distribution and then testing the length that follows to finish the comparison and thus reach the result that It helps in choosing the most suitable HE with the best length for different engineering applications.

\section{3- Results and Discussion}

The results of this work are based on studying the effect of HE length for different types, including parallel and counter HE with a hot substance flowrate equal to $0.2 \mathrm{k}$ and $0.3 \mathrm{~kg} / \mathrm{s}$ for the cold substance. The effect of the HE length has been studied for several lengths, which are 10, 15, 20, and $25 \mathrm{~m}$ of the mentioned systems. Where it is found inside the parallel HE with liquid water medium, the heat transfer was increased by increasing the length of the heat transfer as it was $42.9 \mathrm{~kW}$ for the length of $10 \mathrm{~m}, 47.6 \mathrm{~kW}$ for the length of $15 \mathrm{~m}, 49.5 \mathrm{~kW}$ for the length of $20 \mathrm{~m}$, and $50.2 \mathrm{~kW}$ for the length of $25 \mathrm{~m}$. Figures 4A to 4D and Figures 5A to 5D show the temperature distribution inside the parallel HE with liquid medium between the hot and cold substances as it is clear that the temperature difference gap decreases by increasing the HE length as well as the heat transfer rate.

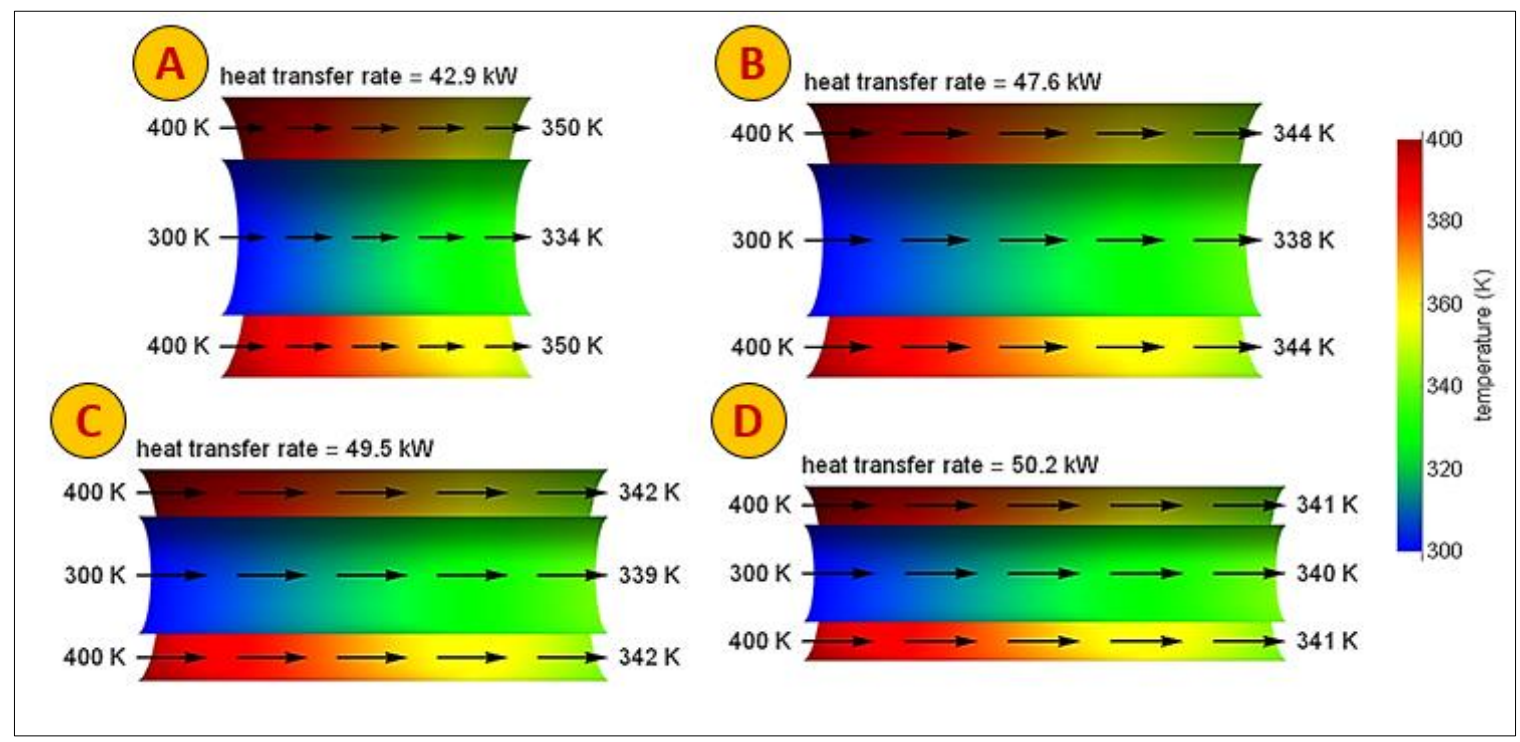

Figure 4. Parallel HE with length of (A), $10 \mathrm{~m}(\mathrm{~B}), 15 \mathrm{~m}$ (C), $20 \mathrm{~m}$ and (D) $25 \mathrm{~m}$

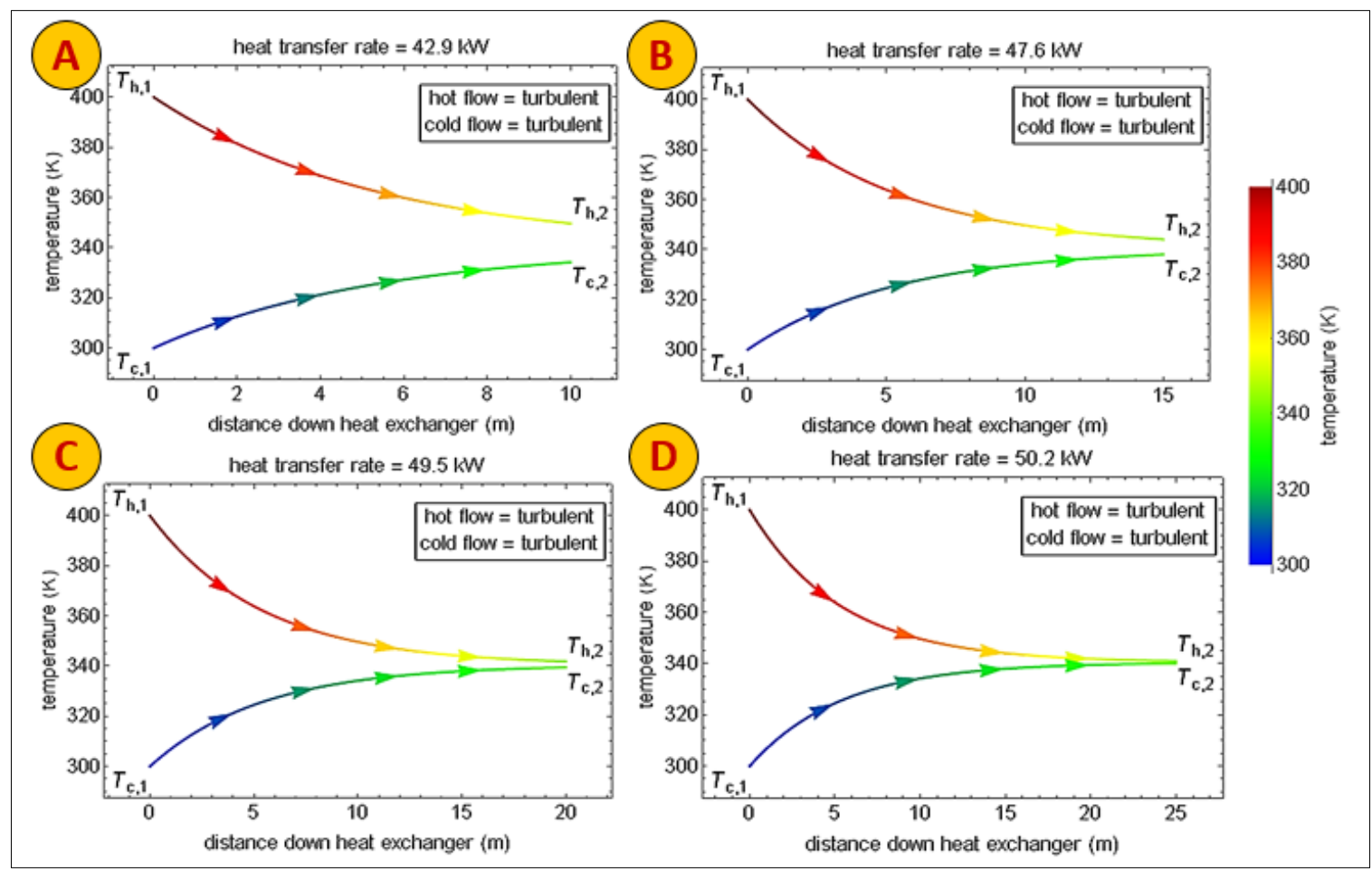

Figure 5. Parallel HE temperature distribution at length of (A), $10 \mathrm{~m}(\mathrm{~B}), 15 \mathrm{~m}(\mathrm{C}), 20 \mathrm{~m}$, and (D) $25 \mathrm{~m}$ 
Figures $6 \mathrm{~A}$ to $6 \mathrm{D}$ show the heat exchange process in the counter HE where it was found that by increasing the length of the HE the heat transfer is increasing as well where the heat transfer was $48.7 \mathrm{~kW}$ inside the HE with $10 \mathrm{~m}$ length, $58.6 \mathrm{~kW}$ inside the $15 \mathrm{~m}$ length $\mathrm{HE}, 65.1 \mathrm{~kW}$ inside the $20 \mathrm{HE}$ length, and $69.6 \mathrm{~kW}$ inside the $25 \mathrm{~m}$ length HE. through the comparison between the parallel and counter HEs it was found that the counter HE is more efficient in the heat transfer as the values of the heat transfer rates is more in the counter HE compared to the parallel HE. Figure 7 A to D shows the temperature distribution inside the counter HE. It is clear that the temperature difference gap in the counter $\mathrm{HE}$ decreases with increasing the length of the $\mathrm{HE}$ as well as the heat transfer rate.

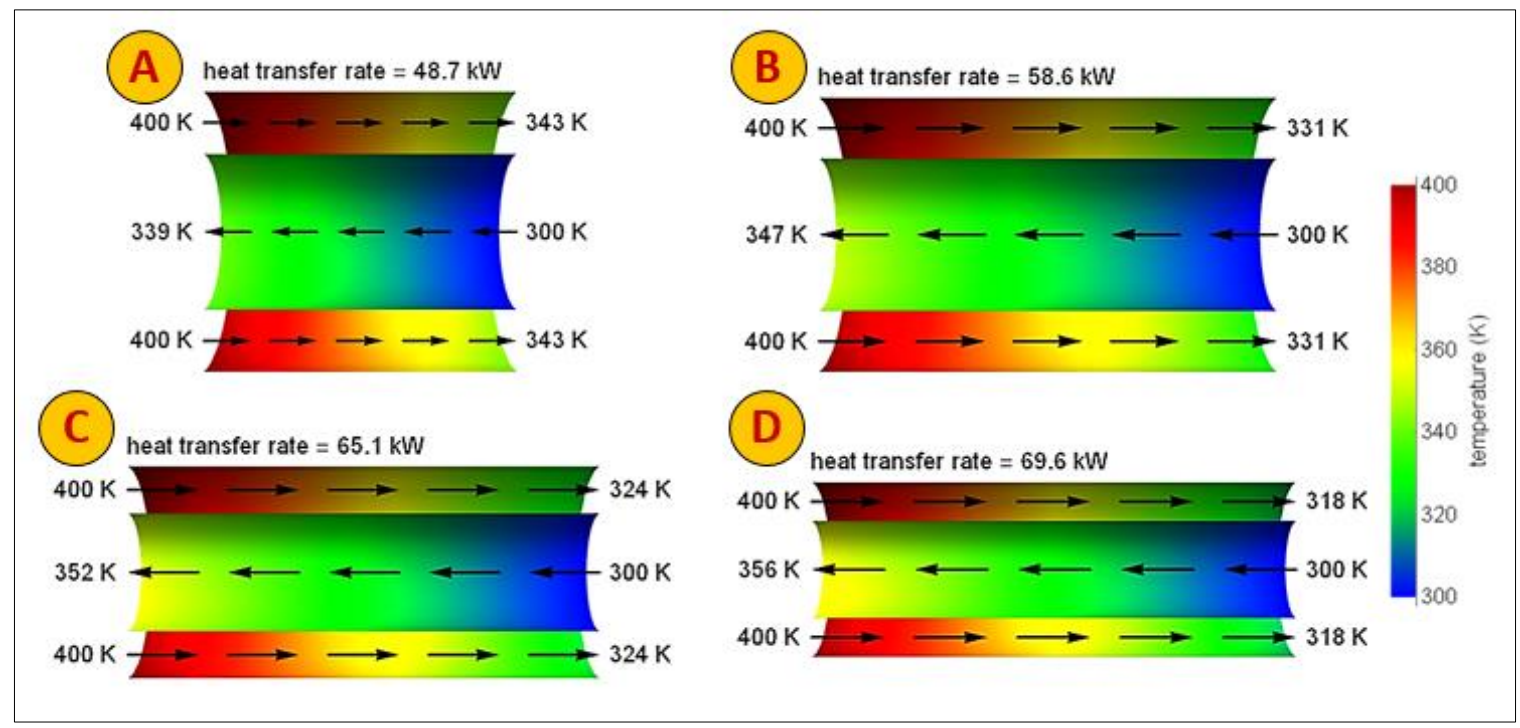

Figure 6. Counter HE with length of (A), $10 \mathrm{~m}(\mathrm{~B}), 15 \mathrm{~m}(\mathrm{C}), 20 \mathrm{~m}$, and (D) $25 \mathrm{~m}$

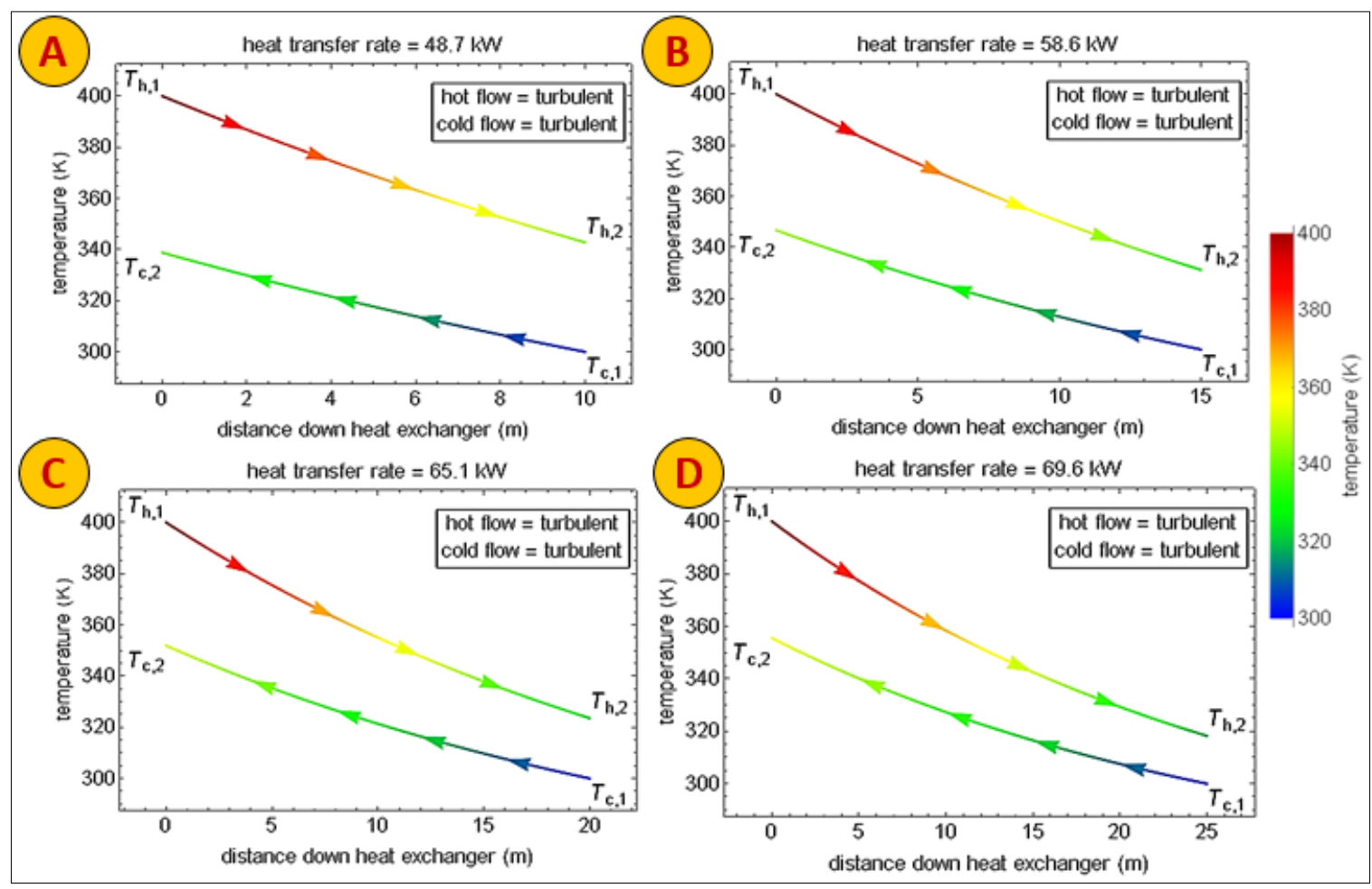

Figure 7. Counter HE temperature distribution at length of (A), $10 \mathrm{~m}(\mathrm{~B}), 15 \mathrm{~m}(\mathrm{C}), 20 \mathrm{~m}$, and (D) $25 \mathrm{~m}$

The temperature profile for both HE parallel and counter shows two disadvantage which is the thermal stresses due to the large temperature difference at the end and the huge temperature difference gap which make the cold substance never reach the lowest temperature of the hot substance. The counter flow HE shows more advantages compared to the parallel heat flow exchanger which is a more uniform temperature difference distribution, the cold substance can reach the hot substance entrance temperature and more heat transfer homogenous distribution. 
The results show the effect of the design conditions on the performance of the HEs, as we found that the length of the HE plays a major role in influencing the increase in heat exchange between the materials used in the HE (hot-cold). The heat exchange performance increases in the two types of HEs used, which are the parallel-flow exchanger and the counter-flow exchanger. The reason for the increase in the efficiency of the heat exchanges with increasing length is due to the increase in the surface area of the heat exchange and the increase in the time period to which the heat transfer materials are exposed between them. The results also show that the counter-flow HE has a higher efficiency than the parallel-flow HE because of the higher temperature difference in the counter-flow HE compared to the parallel-flow exchanger.

Many researchers studied the problems with HEs and ways to improve the quality of heat transfer in HEs. Here we found Wang et al. [46] who studied the increase in the heat exchange area, and they found that the efficiency of the HE increased, which is what was supported in this study. Zheng et al. [49] also studied the shape of the HE channels and found that by modifying the HE design internally, the efficiency of the HE is improved. Here we also found that this study supports this idea and develops the scientific content of that hypothesis.

\section{4- Conclusion}

Overall, this study is based on verifying the design conditions of parallel and counter-flow HEs, and in particular, studying the effect of increasing the length of the HEs on the efficiency of heat exchange. As it becomes clear from these results, the heat distribution within the HEs, whether in parallel or counter flow, is more homogeneous. The reason for the increase in the efficiency of HEs by increasing the length is due to the increase in the surface area of heat exchange and the increase in the time period for heat exchange processes inside the HEs. It was also found that by comparing the parallel and counter-flow HEs, the counter-flow HEs have a higher efficiency, and this is due to the reason of the temperature difference between the ends of the HE, which is higher than the temperature difference in the parallel-flow HE. In general, it is found that the change in the design conditions of HEs of different types often has an impact on increasing the efficiency of heat exchange. This is supported by previous research and scientific studies, and here it is recommended that studying the improvement of new design conditions is necessary to increase the efficiency of HEs in the future..

\section{5- Nomenclature}

\begin{tabular}{|c|c|c|c|c|c|}
\hline $\mathrm{U}$ & Overall heat coefficient & $\mathrm{q}$ & Heat transfer & $\mathrm{T}_{\mathrm{h}, \mathrm{o}}$ & Temperature, hot outlet \\
\hline A & Area & $\dot{m}_{h}$ & Mass flowrate, hot side & $\mathrm{T}_{\mathrm{c}, \mathrm{o}}$ & Temperature, cold outlet \\
\hline $\mathrm{R}_{\mathrm{w}}$ & Conduction resistance & $\mathrm{i}_{\mathrm{c}, \mathrm{o}}$ & Fluid enthalpy cold side outlet & $\mathrm{T}_{\mathrm{c}, \mathrm{i}}$ & Temperature, cold inlet \\
\hline $\mathrm{R}_{\mathrm{f}, \mathrm{c}}$ & Fouling factor, cold side & $\mathrm{i}_{\mathrm{c}, \mathrm{i}}$ & Fluid enthalpy cold side inlet & $\mathrm{T}_{\mathrm{h}, \mathrm{i}}$ & Temperature, hot inlet \\
\hline$\dot{m}_{c}$ & Mass flowrate, cold side & $\mathrm{ihh}_{\mathrm{h}, \mathrm{o}}$ & Fluid enthalpy hot side outlet & $\eta_{f}$ & Fin efficiency \\
\hline $\mathrm{R}_{\mathrm{f}, \mathrm{h}}$ & Fouling factor, hot side & $\mathrm{in}_{\mathrm{h}, \mathrm{i}}$ & Fluid enthalpy hot side inlet & $\Delta T_{m}$ & mean temperature difference \\
\hline$\eta_{o}$ & Temperature effectiveness & $\mathrm{C}_{\mathrm{p}, \mathrm{h}}$ & Specific heat at constant pressure, hot side & & \\
\hline $\mathrm{A}_{\mathrm{f}}$ & Fin surface area & $\mathrm{C}_{\mathrm{p}, \mathrm{c}}$ & Specific heat at constant pressure, cold side & & \\
\hline
\end{tabular}

\section{6- Declarations}

\section{6-1-Author Contributions}

Conceptualization, S.S.A.; methodology, A.M.A.; software, M.A.M.; validation, H.A.; formal analysis, S.S.A.; investigation, A.M.A.; resources, M.A.M.; data curation, S.S.A.; writing-original draft preparation, H.A.; writingreview and editing, A.M.A.; visualization, S.S.A.; supervision, S.S.A.; project administration, S.S.A.; funding acquisition, S.S.A. All authors have read and agreed to the published version of the manuscript.

\section{6-2-Data Availability Statement}

The data presented in this study are available on request from the corresponding author.

\section{6-3- Funding and Acknowledgements}

I gratefully acknowledge the funding of the Project Number 428/2021, by the deanship of academic research - Mutah University, Jordan. This work is done by the researcher under Mutah University (Jordan) regulation and policy.

\section{6-4-Conflicts of Interest}

The authors declare that there is no conflict of interests regarding the publication of this manuscript. In addition, the ethical issues, including plagiarism, informed consent, misconduct, data fabrication and/or falsification, double publication and/or submission, and redundancies have been completely observed by the authors. 


\section{7- References}

[1] Al-Falahat, A. M., Kardjilov, N., Khanh, T. V., Markötter, H., Boin, M., Woracek, R., ... \& Manke, I. (2019). Energy-selective neutron imaging by exploiting wavelength gradients of double crystal monochromators - Simulations and experiments. Nuclear Instruments and Methods in Physics Research Section A: Accelerators, Spectrometers, Detectors and Associated Equipment, 943, 162477. doi:10.1016/j.nima.2019.162477.

[2] Al-Najideen, M. I., \& Alrwashdeh, S. S. (2017). Design of a solar photovoltaic system to cover the electricity demand for the faculty of Engineering-Mu'tah University in Jordan. Resource-Efficient Technologies, 3(4), 440-445. doi:10.1016/j.reffit.2017.04.005.

[3] Alrwashdeh, S. S. (2022). Energy sources assessment in Jordan. Results in Engineering, $13,100329$. doi:10.1016/j.rineng.2021.100329.

[4] Al-Falahat, A. M., Qadourah, J. A., Alrwashdeh, S. S., khater, R., Qatlama, Z., Alddibs, E., \& Noor, M. (2022). Energy performance and economics assessments of a photovoltaic-heat pump system. Results in Engineering, 13, 100324. doi:10.1016/j.rineng.2021.100324.

[5] Alrwashdeh, S. S. (2021). Investigation of the energy output from PV panels based on using different orientation systems in Amman-Jordan. Case Studies in Thermal Engineering, 28, 101580. doi:10.1016/j.csite.2021.101580.

[6] Alrwashdeh, S. S. (2018). The effect of solar tower height on its energy output at Ma'an-Jordan. AIMS Energy, 6(6), 959-966. doi:10.3934/energy.2018.6.959.

[7] Dinh, B. H., Kim, Y.-S., \& Yoon, S. (2022). Experimental and numerical studies on the performance of horizontal U-type and spiral-coil-type ground heat exchangers considering economic aspects. Renewable Energy. doi:10.1016/j.renene.2022.01.001.

[8] Alrwashdeh, S. S. (2018). Modelling of Operating Conditions of Conduction Heat Transfer Mode Using Energy 2D Simulation. Int. J. Online Eng., 14(9), 200-207. doi:10.3991/ijoe.v14i09.9116.

[9] Alrwashdeh, S. S. (2018). Assessment of the energy production from PV racks based on using different solar canopy form factors in Amman-Jordan. International Journal of Engineering Research and Technology, 2018. 5 (10), 15-30.

[10] Chen, Y.-S., Tian, J., Zhu, H.-H., Fu, Y., \& Wang, N.-X. (2021). Experimental and numerical study on thermal performance of a fluoride salt-to-air heat exchanger. Annals of Nuclear Energy, 108876. doi:10.1016/j.anucene.2021.108876.

[11] Alrwashdeh, S. S. (2019). Investigation of Wind Energy Production at Different Sites in Jordan Using the Site Effectiveness Method. Energy Engineering, 116(1), 47-59. doi:10.1080/01998595.2019.12043338.

[12] Zhang, H., Shi, L., Xuan, W., Chen, T., Li, Y., Tian, H., \& Shu, G. (2022). Analysis of printed circuit heat exchanger (PCHE) potential in exhaust waste heat recovery. Applied Thermal Engineering, 204, 117863. doi:10.1016/j.applthermaleng.2021.117863.

[13] Li, H., Zhang, S., Ji, Y., Sun, M., Li, X., \& Sheng, Y. (2022). The influence of catchment scale on comprehensive heat transfer performance about tube fin heat exchanger in numerical calculation. Energy Reports, 8, $147-155$. doi:10.1016/j.egyr.2021.11.045.

[14] Alrwashdeh, S.S. and F.M. Alsaraireh, (2018) Wind energy production assessment at different sites in Jordan using probability distribution functions. ARPN Journal of Engineering and Applied Sciences. 13(20), 8163-8172.

[15] Alrwashdeh, S. S., FMA, M. A. S., Markötter, H., Kardjilov, N., Klages, M., Scholta, J., \& Manke, I. (2018). In-situ investigation of water distribution in polymer electrolyte membrane fuel cells using high-resolution neutron tomography with $6.5 \mu \mathrm{m}$ pixel size. AIMS Energy, 6(4), 607-614. doi:10.3934/energy.2018.4.607.

[16] Alrwashdeh, S. S., \& Ammari, H. (2019). Life cycle cost analysis of two different refrigeration systems powered by solar energy. Case Studies in Thermal Engineering, 16, 100559. doi:10.1016/j.csite.2019.100559.

[17] Alrwashdeh, S. S., Manke, I., Markötter, H., Haußmann, J., Kardjilov, N., Hilger, A., ... \& Banhart, J. (2017). Neutron radiographic in operando investigation of water transport in polymer electrolyte membrane fuel cells with channel barriers. Energy Conversion and Management, 148, 604-610. doi:10.1016/j.enconman.2017.06.032.

[18] Alrwashdeh, S. S., Manke, I., Markötter, H., Klages, M., Göbel, M., Haußmann, J., ... \& Banhart, J. (2017). In operando quantification of three-dimensional water distribution in nanoporous carbon-based layers in polymer electrolyte membrane fuel cells. ACS nano, 11(6), 5944-5949. doi:10.1021/acsnano.7b01720.

[19] Alrwashdeh, S. S., Markötter, H., Haußmann, J., Arlt, T., Klages, M., Scholta, J., ... \& Manke, I. (2016). Investigation of water transport dynamics in polymer electrolyte membrane fuel cells based on high porous micro porous layers. Energy, 102, 161165. doi:10.1016/j.energy.2016.02.075. 
[20] Hang, P., Zhao, L., \& Liu, G. (2022). Optimal design of heat exchanger network considering the fouling throughout the operating cycle. Energy, 241, 122913. doi:10.1016/j.energy.2021.122913.

[21] Göbel, M., Kirsch, S., Schwarze, L., Schmidt, L., Scholz, H., Haußmann, J., ... \& Müller, B. R. (2018). Transient limiting current measurements for characterization of gas diffusion layers. Journal of Power Sources, 402, 237-245. doi:10.1016/j.jpowsour.2018.09.003.

[22] Markötter, H., Manke, I., Böll, J., Alrwashdeh, S., Hilger, A., Klages, M., ... \& Scholta, J. (2019). Morphology correction technique for tomographic in-situ and operando studies in energy research. Journal of Power Sources, 414, 8-12. doi:10.1016/j.jpowsour.2018.12.072.

[23] Hameed, V. M., \& Hamad, F. J. (2022). Implementation of novel triangular fins at a helical coil heat exchanger. Chemical Engineering and Processing - Process Intensification, 172, 108745. doi:10.1016/j.cep.2021.108745.

[24] Saraireh, M.A., F.M. Alsaraireh, and S.S. Alrwashdeh, (2017). Investigation of heat transfer for staggered and in-line tubes. International Journal of Mechanical Engineering and Technology, 8(11), 476-483.

[25] Kuppan, T. (2000). Heat exchanger design handbook, Marcel Dekker, Inc.

[26] Li, N., Chen, J., Cheng, T., Klemeš, J. J., Varbanov, P. S., Wang, Q., ... \& Zeng, M. (2020). Analysing thermal-hydraulic performance and energy efficiency of shell-and-tube heat exchangers with longitudinal flow based on experiment and numerical simulation. Energy, 202, 117757. doi:10.1016/j.energy.2020.117757

[27] Li, N., Wang, J., Klemeš, J. J., Wang, Q., Varbanov, P. S., Yang, W., Liu, X., \& Zeng, M. (2021). A target-evaluation method for heat exchanger network optimisation with heat transfer enhancement. Energy Conversion and Management, 238, 114154. doi:10.1016/j.enconman.2021.114154.

[28] Sun, F., Markötter, H., Manke, I., Hilger, A., Alrwashdeh, S. S., Kardjilov, N., \& Banhart, J. (2017). Complementary X-ray and neutron radiography study of the initial lithiation process in lithium-ion batteries containing silicon electrodes. Applied Surface Science, 399, 359-366. doi:10.1016/j.apsusc.2016.12.093.

[29] Sun, F., Markötter, H., Zhou, D., Alrwashdeh, S. S. S., Hilger, A., Kardjilov, N., Manke, I., \& Banhart, J. (2016). In Situ Radiographic Investigation of (De) Lithiation Mechanisms in a Tin-Electrode Lithium-Ion Battery. ChemSusChem, 9(9), 946950. doi:10.1002/cssc.201600220.

[30] Alrwashdeh, S. S. (2018). Assessment of photovoltaic energy production at different locations in Jordan. International Journal of Renewable Energy Research, 8(2), 797-804.

[31] Alrwashdeh, S. S., Manke, I., Markötter, H., Haußmann, J., Arlt, T., Hilger, A., Al-Falahat, A. M., Klages, M., Scholta, J., \& Banhart, J. (2017). Improved Performance of Polymer Electrolyte Membrane Fuel Cells with Modified Microporous Layer Structures. Energy Technology, 5(9), 1612-1618. doi:10.1002/ente.201700005.

[32] Alsaad, M. A. (2013). Wind energy potential in selected areas in Jordan. Energy Conversion and Management, 65, 704-708. doi:10.1016/j.enconman.2011.12.037.

[33] Ammari, H. D., Al-Rwashdeh, S. S., \& Al-Najideen, M. I. (2015). Evaluation of wind energy potential and electricity generation at five locations in Jordan. Sustainable Cities and Society, 15, 135-143. doi:10.1016/j.scs.2014.11.005.

[34] Palomba, V., Brancato, V., \& Frazzica, A. (2019). Thermal performance of a latent thermal energy storage for exploitation of renewables and waste heat: An experimental investigation based on an asymmetric plate heat exchanger. Energy Conversion and Management, 200, 112121. doi:10.1016/j.enconman.2019.112121.

[35] Popov, D., Fikiin, K., Stankov, B., Alvarez, G., Youbi-Idrissi, M., Damas, A., Evans, J., \& Brown, T. (2019). Cryogenic heat exchangers for process cooling and renewable energy storage: A review. Applied Thermal Engineering, 153, 275-290. doi:10.1016/j.applthermaleng.2019.02.106.

[36] Roux, J., Santarelli, M., \& Aggarwal, S. K. (2018). Design of a Compact Heat Exchanger in a Methanation Plant for Renewable Energy Storage. Applied Thermal Engineering, 129, 747-760. doi:10.1016/j.applthermaleng.2017.10.040.

[37] Yoon, S., Kim, M. J., Jeon, J. S., \& Jung, Y. B. (2021). Significance evaluation of performance factors on horizontal spiral-coil ground heat exchangers. Journal of Building Engineering, 35, 102044. doi:10.1016/j.jobe.2020.102044.

[38] Saleh, B., \& Sundar, L. S. (2021). Experimental study on heat transfer, friction factor, entropy and exergy efficiency analyses of a corrugated plate heat exchanger using Ni/water nanofluids. International Journal of Thermal Sciences, 165, 106935. doi:10.1016/j.ijthermalsci.2021.106935.

[39] Zhu, X., \& Haglind, F. (2020). Relationship between inclination angle and friction factor of chevron-type plate heat exchangers. International Journal of Heat and Mass Transfer, 162, 120370. doi:10.1016/j.ijheatmasstransfer.2020.120370. 
[40] Chen, J., Liu, S., \& Chang, X. (2021). Extragradient method and golden ratio method for equilibrium problems on Hadamard manifolds. International Journal of Computer Mathematics, 98(8), 1699-1712. doi:10.1080/00207160.2020.1846728.

[41] Kozeki, M., Nariai, H., Furukawa, T., \& Kurosu, K. (1970). A study of helically-coiled tube once-through steam generator. Bulletin of JSME, 13(66), 1485-1494. ttps://doi.org/10.1299/jsme1958.13.1485.

[42] Desai, S. R., \& Kengar, R. V. (2019). Experimental analysis of fluid elastic vibrations in rotated square finned tube arrays subjected to water cross flow. Proceedings of the Institution of Mechanical Engineers, Part C: Journal of Mechanical Engineering Science, 233(17), 6124-6134. doi:10.1177/0954406219861132.

[43] Deng, S., Nie, C., Wei, G., \& Ye, W. B. (2019). Improving the melting performance of a horizontal shell-tube latent-heat thermal energy storage unit using local enhanced finned tube. Energy and Buildings, 183, 161-173. doi:10.1016/j.enbuild.2018.11.018.

[44] Klemes, J. J., Arsenyeva, O., Kapustenko, P., \& Tovazhnyanskyy, L. (2019). Compact heat exchangers for energy transfer intensification: low grade heat and fouling mitigation. CRC Press.

[45] Guo, K., Zhang, N., \& Smith, R. (2015). Optimisation of fin selection and thermal design of counter-current plate-fin heat exchangers. Applied Thermal Engineering, 78, 491-499. doi:10.1016/j.applthermaleng.2014.11.071.

[46] Wang, Z., \& Li, Y. (2016). Layer pattern thermal design and optimization for multistream plate-fin heat exchangers - A review. Renewable and Sustainable Energy Reviews, 53, 500-514. doi:10.1016/j.rser.2015.09.003.

[47] Kapustenko, P. O., Klemeš, J. J., Matsegora, O. I., Arsenyev, P. Y., \& Arsenyeva, O. P. (2019). Accounting for local thermal and hydraulic parameters of water fouling development in plate heat exchanger. Energy, 174, $1049-1059$. doi:10.1016/j.energy.2019.03.026.

[48] Figley, J., Sun, X., Mylavarapu, S. K., \& Hajek, B. (2013). Numerical study on thermal hydraulic performance of a Printed Circuit Heat Exchanger. Progress in Nuclear Energy, 68, 89-96. doi:10.1016/j.pnucene.2013.05.003.

[49] Zheng, Z., Fletcher, D. F., \& Haynes, B. S. (2014). Transient laminar heat transfer simulations in periodic zigzag channels. International Journal of Heat and Mass Transfer, 71, 758-768. doi:10.1016/j.ijheatmasstransfer.2013.12.056.

[50] Ma, T., Li, L., Xu, X. Y., Chen, Y. T., \& Wang, Q. W. (2015). Study on local thermal-hydraulic performance and optimization of zigzag-type printed circuit heat exchanger at high temperature. Energy Conversion and Management, 104, 55-66. doi:10.1016/j.enconman.2015.03.016.

[51] Sharma, H., Monnier, É., Mandil, G., Zwolinski, P., \& Colasson, S. (2019). Comparison of environmental assessment methodology in hybrid energy system simulation software. Procedia CIRP, 80, 221-227. doi:10.1016/j.procir.2019.01.007

[52] Zou, Y., Xiang, K., Zhan, Q., \& Li, Z. (2021). A simulation-based method to predict the life cycle energy performance of residential buildings in different climate zones of China. Building and Environment, 193, 107663. doi:10.1016/j.buildenv.2021.107663.

[53] Gobakis, K., \& Kolokotsa, D. (2017). Coupling building energy simulation software with microclimatic simulation for the evaluation of the impact of urban outdoor conditions on the energy consumption and indoor environmental quality. Energy and Buildings, 157, 101-115. doi:10.1016/j.enbuild.2017.02.020.

[54] Alaqel, S., Saleh, N. S., Djajadiwinata, E., Saeed, R., Alswaiyd, A., Al-Ansary, H., El-Leathy, A., Zeitoun, O., Jeter, S., AbdelKhalik, S., Khayyat, A., Danish, S., \& Al-Suhaibani, Z. (2021). A novel particle-to-fluid direct-contact counter-flow heat exchanger for CSP power generation applications: Design features and experimental testing. Renewable Energy, 170, 905-926. doi:10.1016/j.renene.2021.02.049. 